\title{
Development of a Species-Specific PCR for Detection and Quantification of Meloidogyne hapla in Soil Using the 16D10 Root-Knot Nematode Effector Gene
}

\author{
Adrienne M. Gorny, ${ }^{1}$ Xiaohong Wang, ${ }^{1,2}$ Frank S. Hay, ${ }^{1}$ and Sarah J. Pethybridge ${ }^{1, \dagger}$ \\ ${ }^{1}$ Plant Pathology and Plant-Microbe Biology Section, School of Integrative Plant Science, Cornell AgriTech at the New York \\ State Agricultural Experiment Station, Cornell University, Geneva, NY 14456 \\ ${ }^{2}$ Robert W. Holley Center for Agriculture and Health, U.S. Department of Agriculture Agricultural Research Service, Ithaca, NY \\ 14850
}

\begin{abstract}
The Northern root-knot nematode (Meloidogyne hapla) is an important soilborne pathogen of numerous agricultural crops in temperate regions. Accurate detection and quantification is vital to supporting informed pest management decisions. However, traditional methods of manual nematode extraction and morphology-based identification are timeconsuming and require highly specialized training. Molecular methods may expand the diagnostician's toolkit beyond those methods that rely on this disappearing specialized skillset. However, molecular assays targeting the internal transcribed spacer region may lead to inaccurate results because of intraspecific variability. The Meloidogyne spp. effector gene $16 D 10$ was assessed as a target for a SYBR Green I quantitative PCR (qPCR) assay for detection and quantification of M. hapla. M. hapla-specific qPCR primers were developed and evaluated for specificity against five $M$. hapla isolates and 14 other plant-parasitic nematodes.

soil. The influence of soil inhibitors on quantitative amplification was assessed by generating a dilution series from DNA extracted from pure nematode cultures and inoculated soil. Extracts from soil produced significantly higher $\mathrm{Cq}$ values than those produced from pure culture extracts. The utility of the qPCR was evaluated using soil samples collected from three naturally infested potato fields, resulting in a significant positive relationship between populations estimated using qPCR and populations derived from manual counting. The qPCR developed in this study provides a useful method for detecting and quantifying M. hapla in soil and demonstrates the utility of effector genes in plantparasitic nematode diagnostics. The ability to use effector genes as targets for qPCR and other molecular detection and quantification methods may open additional avenues of novel research and support development of improved species-level diagnostics.
\end{abstract} A standard curve was generated by relating the quantification cycle $(\mathrm{Cq})$ to the $\log$ of $M$. hapla population densities artificially introduced into
Keywords: pathogen detection, vegetables
Root-knot nematodes (RKNs; Meloidogyne spp.) are sedentary endoparasites in which second-stage juveniles (J2) invade roots, establish specialized feeding sites, and pass through two further juvenile stages (J3 and J4) to become adults. Adult females are swollen and release eggs in a gelatinous matrix outside the root surface (Jones et al. 2013; Perry et al. 2009). Second-stage juveniles and males constitute the motile life stages. Typical symptoms of RKN include galls on roots and reduced root volume resulting in nondescript aboveground symptoms such as chlorosis, wilting, and stunting (Duncan and Phillips 2009).

The Northern RKN, M. hapla Chitwood, has a broad host range and cosmopolitan occurrence, yet is of particular importance in temperate agricultural regions (Perry et al. 2009). M. hapla can cause significant reductions in yield and crop quality on a broad range of economically important annual crops, including Solanum spp. (nightshade family, including potato [S. tuberosum]; van der Beek et al. 1998), carrot (Sapkota et al. 2016; Vrain 1982), and soybean (Barker and Olthof 1976), and numerous perennial crops, including

${ }^{\dagger}$ Corresponding author: S. J. Pethybridge; sjp277@ cornell.edu

Funding: This work was supported financially by a U.S. Department of Agriculture National Institute of Food and Agriculture (USDA-NIFA) Crop Protection and Pest Management grant (project number NYG-625581), a USDANIFA Education and Literacy Initiative Predoctoral Fellowship (award number 2018-67011-28072), a Northeast Sustainable Agriculture Research and Education Graduate Student grant (project number GNE15-103), and a USDA Agricultural Research Service-State Partnership Potato Program award (agreement number 8062-22000-021-04S).

The author(s) declare no conflict of interest.

Accepted for publication 15 February 2019

(C) 2019 The American Phytopathological Society grapevine (Walker 1997) and coffee (Handoo et al. 2005). Reductions in yield vary with crop and production region. In tomato, Barker et al. (1976) measured yield losses up to $50 \%$ in microplots infested with $25 \mathrm{eggs} / \mathrm{cm}^{3}$ of soil. In carrot and lettuce, two highly sensitive crops, damage and yield reductions exceeded economic thresholds at $<10$ eggs $/ \mathrm{cm}^{3}$ (Gugino et al. 2006; Viaene and Abawi 1996). Many weed species and some cover crops, such as alfalfa, are also host to M. hapla (Griffin and Elgin 1977; Rich et al. 2008), making the development of comprehensive management strategies complex.

Effective management of $M$. hapla primarily relies on strategies prior to planting. A commonly used management strategy consists of soil treatment, with either a fumigant (e.g., methyl bromide, metam sodium) or nonfumigant (e.g., oxamyl) nematicides (Mitkowski and Abawi 2003). Management strategies may also include rotation to a nonhost crop such as cereals (van der Beek et al. 1998), or field fallow, which may attenuate populations by removing the presence of a susceptible host. The primary objective of these strategies is to reduce initial $M$. hapla populations below the preplant economic threshold to limit the damage in the following crop (Barker and Olthof 1976; Madden et al. 2007). In many cropping systems, a significant inverse correlation describes nematode populations prior to planting and crop loss (Barker and Olthof 1976; Seinhorst 1965). High populations prior to, or at, planting may lead to an increased infection rate during initial stages of the epidemic, leading to high disease severity and damage (Madden et al. 2007). This relationship has been observed for $M$. hapla in many pathosystems, including potato, tomato, and carrot (Barker et al. 1976; Gugino et al. 2006; Olthof and Potter 1972; Wheeler et al. 1994). Therefore, accurate pathogen detection and quantification is important for supporting informed disease management decisions and crop loss prediction models for $M$. hapla and other plant-parasitic nematodes. Within-season control may include the use of resistant varieties and cultivars, yet few highly sensitive crops have significant practical resistance (Roberts 1992). For example, no genetic resistance to M. hapla is available in 
commercially cultivated potato (Janssen et al. 1995; Melakeberhan et al. 2007; van der Beek et al. 1998).

In developing an integrated management plan for M. hapla, accurate and rapid detection and quantification of populations to the species level is critical (Madden et al. 2007). However, identification of plant-parasitic nematodes to species by observation of morphological characteristics is technically challenging and requires advanced training and experience (Min et al. 2012; Sapkota et al. 2016). Furthermore, quantification of populations using methods such as Baermann funnels or bioassays is time-consuming (Ophel-Keller et al. 2008), requiring days to weeks to provide information on nematode populations. Molecular identification of species provides an attractive alternative to morphology-based methods. Detection and differentiation of economically important Meloidogyne spp. has been accomplished using molecular-based techniques, such as restriction fragment analysis (Curran et al. 1986), PCR (Dong et al. 2001; Wishart et al. 2002; Zijlstra 1997), quantitative PCR (qPCR) (Hay et al. 2016; Sapkota et al. 2016; Sawada et al. 2011), loopmediated isothermal amplification (Niu et al. 2011; Peng et al. 2017), random amplified polymorphic DNA fingerprinting (Adam et al. 2007; Randig et al. 2001), and high-resolution melt curve analysis (Holterman et al. 2012). Molecular methods offer advantages in being able to process many samples in parallel with a reduced processing lag time, and circumvent diagnostic limitations of RKN species based on morphology at the juvenile stage, which may lack distinctive features necessary for diagnostic certainty. qPCR offers additional advantages in simultaneous detection and quantification of DNA from a range of media to enable estimation of populations.

Numerous qPCR assays have been described for the detection and quantification of important plant-parasitic nematodes, including Globodera rostochiensis (Goto et al. 2010; Toyota et al. 2008), M. javanica (Berry et al. 2008), M. incognita (Sawada et al. 2011), M. fallax (Hay et al. 2016; Zijlstra and Van Hoof 2006), M. hapla (Hay et al. 2016; Sapkota et al. 2016), M. enterolobii (Braun-Kiewnick et al. 2016), M. chitwoodi (Zijlstra and Van Hoof 2006), Paratrichodorus allius (Huang et al. 2017), Pratylenchus zeae (Berry et al. 2008), Pratylenchus thornei (Yan et al. 2010), Pratylenchus penetrans (Baidoo et al. 2017; Mokrini et al. 2013), Pratylenchus neglectus (Yan et al. 2013), Pratylenchus scribneri (Huang and Yan 2017), Ditylenchus destructor, D. dipsaci, D. gigas (Jeszke et al. 2015), and Xiphinema elongatum (Berry et al. 2008). These qPCR assays use the internal transcribed spacer (ITS) ribosomal DNA (rDNA) region as a target for primer and probe sequences. Intraspecies variability of the ITS rDNA region has been observed in many plant-parasitic nematode species, including Nacobbus aberrans (Anthoine and Mugniéry 2005), Bursaphelenchus spp. (Prospero et al. 2015), P. neglectus (Hafez et al. 1999), and Ditylenchus spp. (Huang et al. 2010; Jeszke et al. 2015). Madani et al. (2010) noted that populations of G. rostochiensis contained several ITS haplotypes, concluding that the ITS region is not an ideal target region. Other studies have also reported a high degree of heterogeneity within the ITS rDNA region of other genera, even within individual nematodes (Hugall et al. 1999; Powers et al. 1997; Zijlstra et al. 1995). Regarding RKN, Kiewnick et al. $(2014,2015)$ and Holterman et al. (2012) suggested that because of the intraspecies variability measured in the ITS, this region is suitable for identification at the genus level but not the species level. Conversely, some research has noted that Meloidogyne spp. are highly similar within the ITS. Handoo et al. (2005) were unable to distinguish M. javanica from M. hapla within the ITS region as a result of little polymorphism between species. Moreover, García and Sánchez-Puerta (2012) were unable to distinguish between $M$. arenaria, $M$. javanica, and $M$. incognita. Identification and quantification of Meloidogyne spp. and other plant-parasitic nematodes based on the ITS rDNA therefore has limited utility as a result of error from intraspecies variability and heterogeneity, potential nonspecific amplification among nontarget nematode species, and potential underestimation of true population densities. For example, the qPCR developed for M. hapla based on the ITS region by Sapkota et al. (2016) reported low specificity and a cross-reaction with $M$. minor. Moreover, the qPCR developed for M. hapla detection by Hay et al. (2016) did not observe cross-reactions with similar species in silico, yet the species specificity of the assay in vitro using nematode isolates was not investigated.

Other molecular markers in taxonomically informative regions have been successfully used for species-level discrimination, with each offering unique advantages and limitations. Sequence characterized amplified regions have been used in conventional PCR and qPCR to distinguish Meloidogyne spp. (Agudelo et al. 2011; Zijlstra 2000), yet these are not suited to multiplexing or high-throughput analysis (Braun-Kiewnick and Kiewnick 2018) and in some cases may be difficult to amend to a quantifiable assay such as qPCR. The cytochrome oxidase I and II (COI and COII) genes in the mitochondrial DNA are conserved and can provide a species-specific assay (Kiewnick et al. 2015; Toumi et al. 2015). Additionally, the large subunit (D2 to D3) and small subunit (D1 to D2) rDNA are highly conserved and are important targets for designing species-specific molecular assays (Kiewnick et al. 2014, 2015; Rybarczyk-Mydłowska et al. 2012). Similar to the ITS region, the intergenic spacer regions (IGS1 and IGS2) have been used to identify Meloidogyne spp. (e.g., Petersen et al. 1997; Wishart et al. 2002), yet the regions have also shown intraspecies variability and may not be suitable for specieslevel discrimination (Braun-Kiewnick and Kiewnick 2018).

Many economically important plant-parasitic nematodes species are obligate biotrophs that initiate close parasitic relationships with their hosts (Jones et al. 2013; Mitchum et al. 2013). During root penetration, migration, and feeding site establishment, plant-parasitic nematodes secrete numerous types of effector molecules (Mitchum et al. 2013). These effector molecules are composed of small proteins or molecules that alter the host's cell structure and metabolism to assist in the nematodes' entry into and feeding from plant cells (Mitchum et al. 2013; Rehman et al. 2016), resulting in cell damage and reduced root function. Effectors involved in host modification include chorismate mutase (Lambert et al. 1999; Yu et al. 2011), endoglucanases (Gao et al. 2004), 16 D10 in Meloidogyne spp. (Huang et al. 2006a), and pectate lyases (Bakhetia et al. 2007; Vanholme et al. 2007). Other secreted effector molecules suppress host immune responses or inactivate host-produced nematicidal compounds, allowing the nematode to feed with impunity (Haegeman et al. 2012; Smant and Jones 2011). Although some effector genes have homologs in bacteria and fungi derived from early horizontal gene transfer events, many others are specific to plant-parasitic nematodes (Haegeman et al. 2012). Furthermore, unique species of plantparasitic nematodes produce distinctive effectors (Smant and Jones 2011), which may be harnessed for molecular diagnostics. For example, Yu et al. (2011) were successful in distinguishing between the cyst nematode species $G$. rostochiensis, G. pallida, and G. tabacum using the chorismate mutase effector gene found in cyst and RKN species (Jones et al. 2003). Furthermore, Mokrini et al. (2013, 2014) were able to design a specific and sensitive assay for detection of the root lesion nematodes $P$. penetrans and $P$. thornei using the $\beta$-1,4-endoglucanase gene. Here, we investigate the use of the Meloidogyne spp. effector gene $16 \mathrm{D} 10$ as a target for the detection and quantification of $M$. hapla in qPCR to explore the potential of a broader range of molecular markers for plant-parasitic nematode diagnostics. The $16 \mathrm{D} 10$ gene encodes a secreted peptide thought to interact with a plant transcription factor to induce host root growth (Huang et al. 2006a, b) and shown to be essential for parasitism in Meloidogyne spp. (Huang et al. 2006b).

The primary objective of this study was to develop and validate a qPCR for the species-specific detection of M. hapla using the $16 D 10$ effector gene. A secondary objective was to evaluate the potential of this assay to detect and quantify $M$. hapla from DNA extractions conducted from soil.

\section{Materials and Methods}

Preparation of nematodes and DNA isolation from pure cultures and soil. To isolate DNA from pure cultures, M. hapla was reared and maintained in a hydroponics system (Gorny et al. 2018). Second-stage juveniles were observed under a microscope, removed from the reservoir water with an ultrafine dental pick 
(Dentsply Flexofile size 006, $25 \mathrm{~mm}$ ), and placed in $500 \mu \mathrm{l}$ of sterile Type I ultrapure water. The dental pick was examined after each transfer to ensure nematode deposition. The nematode suspension was centrifuged at $10,000 \times g$ for $5 \mathrm{~min}$ and the supernatant was removed. The remaining moisture was removed by centrifuging for $15 \mathrm{~min}$ in a vacufuge concentrator (Eppendorf, Hauppauge, NY). DNA isolation from the nematode pellet was performed as described by Yan et al. (2008) with slight modifications described here. Briefly, in a $1.5-\mathrm{ml}$ microcentrifuge tube, $80 \mu \mathrm{l}$ of lysis buffer $(500 \mathrm{mM} \mathrm{KCl}$, $100 \mathrm{mM}$ Tris- $\mathrm{HCl}$ [pH 8.3], $15 \mathrm{mM} \mathrm{MgCl} 2,10 \mathrm{mM}$ dithiothreitol, $4.5 \%$ Tween-20, and $0.1 \%$ gelatin) was added and the mixture was vortexed briefly to disrupt the pellet. The lysis buffer suspension was incubated at $-20^{\circ} \mathrm{C}$ until frozen. Suspensions were then thawed and $20 \mu \mathrm{l}$ of Proteinase K $(20 \mathrm{mg} / \mathrm{ml})$ was added. The mixture was then incubated at $65^{\circ} \mathrm{C}$ for $1 \mathrm{~h}$, transferred to $95^{\circ} \mathrm{C}$ for $10 \mathrm{~min}$ to deactivate the Proteinase $\mathrm{K}$, and centrifuged at 13,200 $\times \mathrm{g}$ for $5 \mathrm{~min}$, and the supernatant containing the DNA template was transferred to a new tube.

To isolate DNA from soil, M. hapla $\mathrm{J} 2$ for each experiment were similarly inoculated onto $0.5 \mathrm{~g}$ of autoclaved soil mix (3 parts topsoil: 1 part sand; Sensenig Landscape Supply, Geneva, NY). Genomic DNA was isolated from the inoculated soil using the DNeasy PowerSoil DNA isolation kit (Qiagen, Valencia, CA) according to the manufacturer's instructions, with the modification that $0.5 \mathrm{~g}$ of soil was used and the final elution volume was $60 \mu l$.

DNA concentrations were determined using a Qubit fluorometer (Thermo Fisher Scientific, Waltham, MA). Resultant DNA from soil and pure culture, and DNA of other $M$. hapla isolates and nontarget nematode species (Table 1), was stored at $-20^{\circ} \mathrm{C}$ in TE buffer (10 mM Tris-HCl, 0.1 mM EDTA, pH 8.3).

Development of species-specific primers. All available sequences of the $16 D 10$ effector gene from Meloidogyne spp. were obtained from GenBank (M. javanica, DQ841121; M. arenaria, DQ841122; M. hapla, DQ841123; Huang et al. 2006b; and $M$. incognita, DQ087264; Huang et al. 2006a) and aligned using ClustalW within the software Geneious version 8.1.2 (Kearse et al. 2012). Regions of polymorphism between M. hapla and the other Meloidogyne spp. were assessed for placement of primer binding locations for conventional and qPCR. Primer pairs (forward and reverse) were designed to unique regions within the 16010 sequence among the different Meloidogyne species using Primer3 software (version 4.1.0; Koressaar and Remm 2007; Untergasser et al. 2012). Primer sets were evaluated for annealing temperatures and guanine-cytosine (GC) content, and sets were assessed for self-priming and dimer formation using OligoAnalyzer 3.1 (Integrated DNA Technologies, Coralville, IA). Primer pairs were screened for potential mispriming and nontarget priming using the Primer BLAST function of GenBank. One set, designated as Mha17, was identified as having potentially optimal reaction conditions, a high degree of in silico species specificity, and a low degree of self-polymerization. The primer set Mha17 consisted of the forward Mha17f ( $5^{\prime}$-tgaatagttggtggcetctg- $\left.3^{\prime}\right)$ and reverse Mha17f $\left(5^{\prime}\right.$-tgtgctattccaagggtaaag- $\left.3^{\prime}\right)$. Primers were synthesized by Integrated DNA Technologies.

Primer specificity. The specificity of the Mha17 primers was assessed against DNA from five M. hapla isolates and 14 nontarget plant-parasitic nematode species using conventional PCR from single nematode DNA suspensions (Table 1). Nontarget plantparasitic nematodes were selected on the basis of their ubiquitous prevalence in potato field soils. Reaction mixtures $(15 \mu l)$ contained 1× Standard Taq Reaction Buffer (New England Biolabs, Ipswich, MA), $5 \mathrm{mM}$ of dNTPs, $1 \mathrm{U}$ of Taq DNA polymerase (New England Biolabs), $3 \mathrm{mM}$ each of the Mha17 forward and reverse primers, and $2 \mu l$ of template DNA. The reaction cycle conditions were an initial denaturation step of $95^{\circ} \mathrm{C}$ for $3 \mathrm{~min}$, followed by annealing and extension over 40 cycles of $95^{\circ} \mathrm{C}$ for $30 \mathrm{~s}, 55^{\circ} \mathrm{C}$ for $30 \mathrm{~s}$, and $72^{\circ} \mathrm{C}$ for $1 \mathrm{~min}$, followed by a final extension step of $72^{\circ} \mathrm{C}$ for $5 \mathrm{~min}$. The optimal annealing temperature was determined prior to this reaction cycle through a gradient PCR $\left(53\right.$ to $\left.63^{\circ} \mathrm{C}\right)$. Amplification of the correct target region was first confirmed through separation of PCR products on a $1.5 \%$ agarose gel stained with $1 \times$ GelRed at $50 \mathrm{~V}$ for $120 \mathrm{~min}$. The gel was visualized under ultraviolet light and the band size was compared with a 100-bp ladder (Axygen Scientific, Corning Inc., Corning, NY). Quality of the nematode DNA was checked by performing conventional PCR using the ITS primers rDNA2 and rDNA1.58s (Powers et al. 1997) using the same reaction mixture as above. The reaction cycle conditions for amplification of the ITS region consisted of an initial denaturation step of $95^{\circ} \mathrm{C}$ for

Table 1. Meta-data associated with the plant-parasitic nematodes selected to test specificity of the quantitative PCR (qPCR) primers (Mha17f/Mha17r) developed for detection and quantification of Meloidogyne hapla

\begin{tabular}{|c|c|c|c|c|}
\hline Species & Origin & Source & PCR amplificationa & qPCR signal ${ }^{b}$ \\
\hline Meloidogyne hapla & New York & S. Pethybridge & + & $+(34.39)$ \\
\hline M. hapla & New York & S. Pethybridge & + & $+(36.26)$ \\
\hline M. hapla & New York & S. Pethybridge & + & $+(35.74)$ \\
\hline M. hapla & Netherlands & A. Skantar & + & $+(28.54)$ \\
\hline M. hapla & Australia & N. Perry & + & $+(22.98)$ \\
\hline M. arenaria & Delaware & A. Skantar & - & - \\
\hline M. arenaria & New York & L. Cadle-Davidson & - & - \\
\hline M. chitwoodi & Washington & A. Skantar & - & - \\
\hline M. incognita & Dominican Republic & A. Skantar & - & - \\
\hline M. minor & Unknown & A. Skantar & - & - \\
\hline M. naasi & California & A. Skantar & - & - \\
\hline M. fallax & Belgium & A. Skantar & - & - \\
\hline M. javanica & Unknown & N. Perry & - & - \\
\hline M. enterolobii & North Carolina & E. Davis & - & - \\
\hline Pratylenchus penetrans & New York & S. Pethybridge & - & - \\
\hline P. neglectus & Unknown & A. Skantar & - & - \\
\hline P. thornei & Oregon & A. Skantar & - & - \\
\hline Heterodera schachtii & Oregon & A. Skantar & - & - \\
\hline H. trifolii & Greece & A. Skantar & - & - \\
\hline H. glycines & Delaware & A. Skantar & - & - \\
\hline H. glycines & China & A. Skantar & - & - \\
\hline Ditylenchus destructor & Unknown & A. Skantar & - & - \\
\hline
\end{tabular}

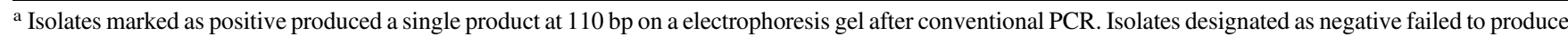
a visible amplicon.

${ }^{\mathrm{b}}$ Isolates marked as positive produced a positive signal during qPCR. Isolates marked as negative produced no signal. Corresponding quantification cycle values from each isolate producing a positive signal are included in parentheses. 
$5 \mathrm{~min}$, then 34 cycles of $95^{\circ} \mathrm{C}$ for $30 \mathrm{~s}, 62^{\circ} \mathrm{C}$ for $30 \mathrm{~s}$, and $72^{\circ} \mathrm{C}$ for 30 $\mathrm{s}$, followed by a final extension step of $72^{\circ} \mathrm{C}$ for $5 \mathrm{~min}$.

To confirm amplification of the target region, PCR products from M. hapla generated using the Mha17 forward and reverse primers were cloned into a pMiniT vector maintained in Escherichia coli using a PCR Cloning Kit (New England Biolabs) according to the manufacturer's instructions. Colonies $(n=35)$ were screened for successful insert of the PCR product and five colonies were selected for plasmid sequencing. Plasmid DNA was extracted using an E.Z.N.A. Plasmid Mini Kit I (OMEGA Bio-Tek, Norcross, GA) and sequenced using the cloning analysis primers included with the PCR Cloning Kit. Sequencing of amplicons (in both directions) was performed at the Cornell University Biotechnology Resource Center (Ithaca, NY) on an Applied Biosystems 3730xl DNA analyzer. Consensus sequences were assembled within Geneious and aligned with full gene sequences of M. hapla $16 D 10$ (full gene sequence, $609 \mathrm{bp}$ ) using the BLAST search function of GenBank.

qPCR. qPCR was performed on a Bio-Rad C1000 CFX96 (BioRad Laboratories, Hercules, CA). Reaction mixtures consisted of $1 \times$ SsoAdvanced Universal Probe Supermix (Bio-Rad), $0.25 \mathrm{M}$ betaine, $0.3 \mathrm{mM}$ additional $\mathrm{MgCl}_{2}, 0.075 \times \mathrm{SYBR}$ Green I (Fisher Scientific, Pittsburgh, PA), $0.25 \mu \mathrm{M}$ of each primer, $5.0 \mu \mathrm{l}$ of template DNA, and water to bring the reaction volume to $20 \mu \mathrm{l}$. Optimal concentrations of the primers were determined in preliminary experiments (data not shown). Amplification conditions consisted of incubation at $95^{\circ} \mathrm{C}$ for $3 \mathrm{~min}$, followed by 50 cycles of $95^{\circ} \mathrm{C}$ for $15 \mathrm{~s}$ and $60^{\circ} \mathrm{C}$ for $30 \mathrm{~s}$ with fluorescence data collected following each combined annealing and extension step. The optimal combined annealing/extension temperature was determined through varying between 55 and $65^{\circ} \mathrm{C}$ (data not shown). A melting curve analysis was performed at the end of the cycling reactions $\left(60\right.$ to $95^{\circ} \mathrm{C}$, in $0.5^{\circ} \mathrm{C}$ increments). Positive (1,000 pg of $M$. hapla DNA), negative ( $800 \mathrm{pg}$ of M. arenaria DNA), and no template (sterile Type I water) controls were included in each assay. A sample was considered negative if no rise in fluorescence was detected by cycle 45 of each run. Three replicates of each sample were included. Intra-assay variability was assessed by including five replicates of the same sample within one assay. Interassay variability was assessed by including the same sample across five separate reaction runs. Reaction conditions were controlled, quantification cycles $(\mathrm{Cq})$ were recorded, and specificity was assessed using CFX Manager software (version 3.1 ; Bio-Rad). Identity of the amplicon was also confirmed by separating products on a $1.5 \%$ agarose gel stained with $1 \times$ GelRed at $50 \mathrm{~V}$ for $120 \mathrm{~min}$.

Generation and validation of the population standard curve. To correlate the $\mathrm{Cq}$ value to $M$. hapla population densities within the soil, 1, 5, 10, 50, 100, and 500 M. hapla $\mathrm{J} 2$ were inoculated into $0.5 \mathrm{~g}$ of autoclaved soil, air dried for 3 days to remove excess moisture, then DNA extracted as described above for soil. Each inoculation level was replicated five times and a noninoculated soil extraction control was included. The samples were assayed in triplicate using the qPCR described above. Resultant Cq values were plotted against the log of the number of inoculated $M$. hapla individuals, and amplification efficiency was calculated. The standard curve was validated by inoculating additional aliquots of $0.5 \mathrm{~g}$ of soil with 3,10 , 25 , and $250 \mathrm{M}$. hapla $\mathrm{J} 2$, and a noninoculated control. The log of predicted population densities from resultant $\mathrm{Cq}$ values and the standard curve were plotted against the log of inoculated population densities.

Assay sensitivity and influence of inhibitory compounds. To investigate the sensitivity of the Mha17 primers (defined here as the lowest number of $M$. hapla $\mathrm{J} 2$ per extraction that produce a visible band on an electrophoresis gel after amplification), DNA was isolated from soil inoculated with 1, 5, 10, and 20 M. hapla $\mathrm{J} 2$ as described above for soil. Each inoculation level was replicated five times. PCR reactions $(15 \mu \mathrm{l})$ were prepared and amplification was assessed as described above for primer specificity testing using conventional PCR. PCR reactions were performed in duplicate.

To investigate the sensitivity of the $\mathrm{qPCR}$ assay and determine the influence of soil inhibitors on reaction efficiency, standard curve assays from serial dilutions of $M$. hapla DNA isolated from both pure culture and soil were performed. DNA was isolated from a suspension of 1,000 M. hapla J2 as described above for pure cultures. Serial dilutions of the DNA were prepared $(1: 1,1: 10,1: 100,1: 1,000$, and 1 : 10,000 representing approximately $790 \mathrm{pg} / \mu \mathrm{l}$ to $0.079 \mathrm{pg} / \mu \mathrm{l}$ of $M$. hapla DNA) using sterile Type I water. DNA concentrations were determined using a Qubit fluorimeter. A similar dilution series was prepared using DNA extracted as described for soil from 1,000 M. hapla $\mathrm{J} 2$ inoculated onto $0.5 \mathrm{~g}$ of sterilized soil. qPCR reactions were performed as described, for each serial dilution step, from pure culture and soil extracts. Reactions were performed in triplicate, and each run included positive (1,000 pg of $M$. hapla DNA), negative ( $800 \mathrm{pg}$ of $M$. arenaria DNA), and no-template negative (sterile Type I water) controls. Standard curves were constructed by plotting the dilution fold change against the $\mathrm{Cq}$ value.

Assessment of field samples. To assess the utility of the Mha17 primers and $\mathrm{qPCR}$ in relating population density estimates derived from the qPCR with those from morphology-based identification, three commercial potato fields in western New York with previous histories of $M$. hapla infestations were selected. One week after planting to potato (cultivars Eva and Genesee), soil samples $(\sim 1 \mathrm{~kg})$ were collected from 100 locations on a regular grid $(15.2 \mathrm{~m} \times 15.2 \mathrm{~m}$ between points) within each field. $M$. hapla population densities were quantified through a modified Whitehead tray (Whitehead and Hemming 1965) for each location. Briefly, a mesh support was nested inside a solid-base pastry baking pan. A milk filter (KenAG, Ashland, $\mathrm{OH}$ ) and a single-ply facial tissue (Kleenex; Kimberly-Clark Corp., Irving, TX) were placed on the mesh support. A subsample of field soil ( $200 \mathrm{~g}$ ) was placed on the supports, and distilled water $(\sim 300 \mathrm{ml})$ was added to the lower pan, gently wetting the soil through the mesh, milk filter, and tissue. Soil was incubated in the dark for $48 \mathrm{~h}$, after which nematodes were collected by passing the water twice through a $25-\mu \mathrm{m}$ mesh sieve held at a $45^{\circ}$ angle. Collected nematode suspensions were adjusted to $25 \mathrm{ml}, 5 \mathrm{ml}$ was removed for quantification under $400 \times$ magnification, and populations were calculated per $200 \mathrm{~g}$ of soil subsample. Ten locations with high populations and 10 locations with low populations, as determined by manual extraction followed by morphology-based enumeration, were selected from across the three fields for assessment using the Mha17 primers and final qPCR conditions described above.

Statistical analysis. Statistical analyses were performed within RStudio (version 3.3.3; R Core Team 2017) after logarithmic transformation of $M$. hapla population densities. The population standard curve was generated by regressing nematode densities and $\mathrm{Cq}$ values obtained from qPCR. The robustness of the standard curve was tested by conducting linear regression analysis to describe the relationship between inoculated validation nematode densities and assaypredicted nematode densities. Differences between $\mathrm{Cq}$ values of serial dilutions from DNA extracts from pure culture and soil were explored using Student's $t$ test at each dilution. The relationship between $M$. hapla population densities predicted from morphology-based counting and qPCR was explored through linear regression.

\section{Results}

Development of species-specific primers. Alignment of sequences of the $16 D 10$ gene from Meloidogyne spp. identified unique regions of polymorphism used to develop species-specific primers for detection and quantification of M. hapla in a qPCR. These primers amplified a 110-bp region of the $16 \mathrm{D} 10$ gene, outside of the predicted coding region. The GC content for the forward and reverse primers was 50 and $40.9 \%$, respectively, and the estimated annealing temperatures were 54.5 and $52.8^{\circ} \mathrm{C}$, respectively. The primers exhibited no matches to nontarget plant-parasitic or free-living nematodes and no strong similarity to other soilborne microorganisms using the BLAST search function of NCBI (Mha17f and Mha17r sequences E-values $\leq 0.3$; next closest alignments E-values $\geq 1.2$ ).

Primer specificity. The primer pair designated Mha17 produced a single amplification band in all M. hapla isolates tested. No amplification was observed in other Meloidogyne spp. or in other nontarget plant-parasitic nematodes assayed (Table 1). Melt curve analysis identified a single peak at $78.5^{\circ} \mathrm{C}$ (Fig. 1). Sequencing of cloning 
products produced nucleotide sequences that were a perfect match to the $16 D 10$ gene sequence DQ841123 in GenBank.

qPCR. The coefficient of variation for intra- and interassay variability was 1.35 and $4.22 \%$, respectively.

Generation and validation of the population standard curve. A standard curve generated by plotting the $\mathrm{Cq}$ values derived from soil inoculated with $1,5,10,50$, and $500 \mathrm{M}$. hapla $\mathrm{J} 2$ per $0.5 \mathrm{~g}$ of soil $(y=$ $-2.949 x+37.01 ; R^{2}=0.9 ; P=0.009 ;$ Fig. 2 ). The efficiency of the reaction was $118.3 \%$ and $\mathrm{Cq}$ values ranged between 29.19 and 44.13. No amplification was observed in the noninoculated soil or nontarget

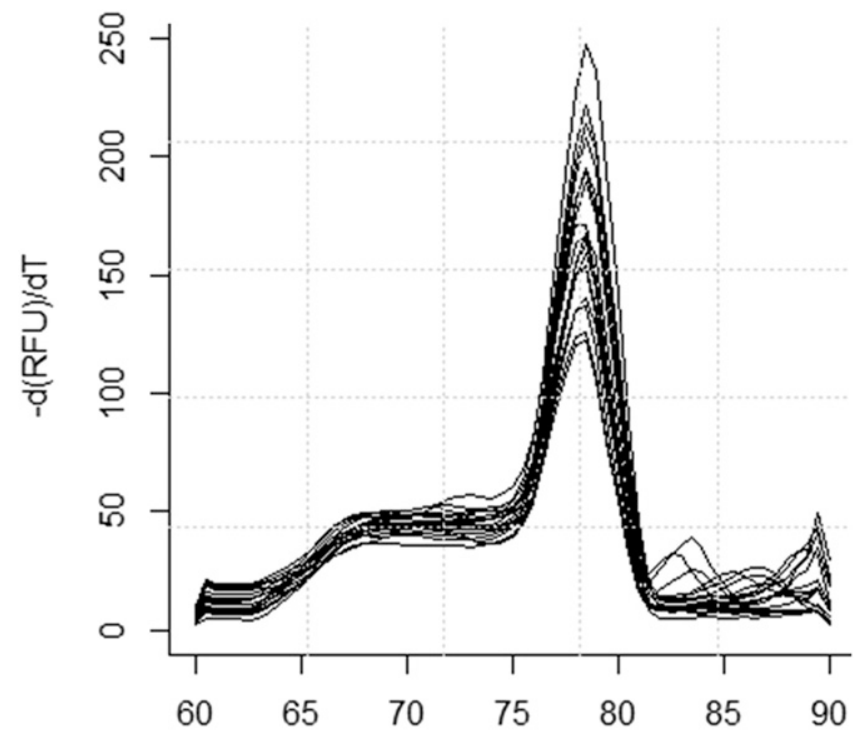

Temperature, Celsius

Fig. 1. Melting curve of Meloidogyne hapla amplicons with a melting temperature of $78.5^{\circ} \mathrm{C}$ using the Mha17f/Mha17r primers developed in this study and DNA of an isolate of $M$. hapla from New York. Reactions not containing M. hapla DNA did not produce a signal.

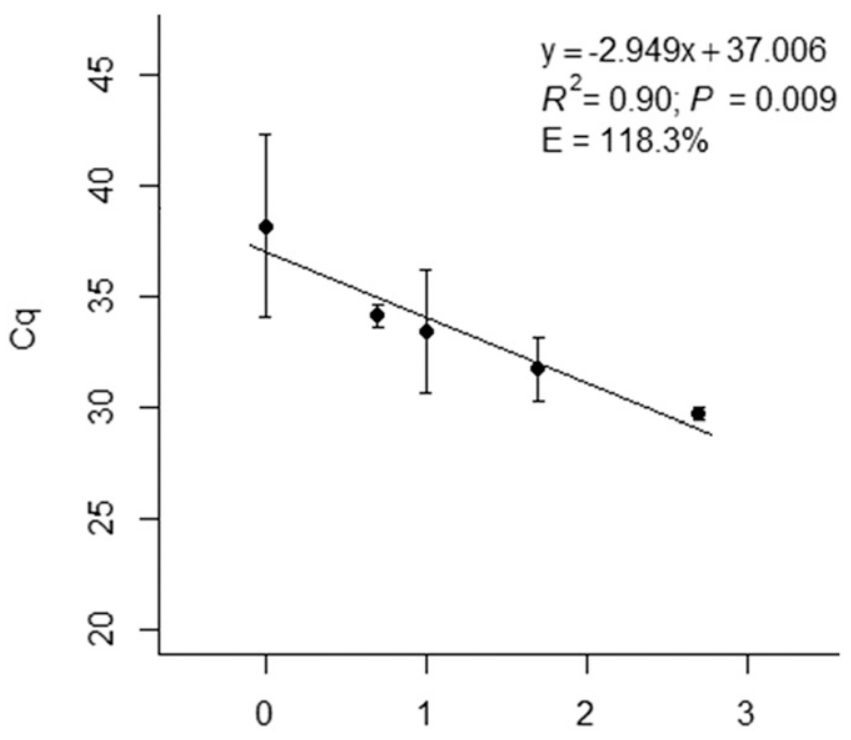

Log Meloidogyne hapla/ $0.5 \mathrm{~g}$ soil

Fig. 2. A standard curve of the quantitative $P C R$ ( $q P C R$ ) using the Mha17f/Mha17r primers for detection and quantification of Meloidogyne hapla based on the 16D10 effector gene. The log of the number of $M$. hapla second-stage juveniles (J2) inoculated in $0.5 \mathrm{~g}$ of soil $(1,5,10,50$, and $500 \mathrm{M}$. hapla J2) is plotted against the resultant quantification cycle $(\mathrm{Cq})$ value. Five replicates of each inoculation level were performed, and the qPCR was conducted in triplicate. species controls. The population standard curve was validated with DNA isolated from soil inoculated with 3, 10, 25, and $250 \mathrm{M}$. hapla $\mathrm{J} 2$ per $0.5 \mathrm{~g}$ of soil. A significant linear relationship was observed between the $\log$ inoculated population density and the log estimated population density derived from the standard curve $(y=1.281 x+$ $0.001 ; R^{2}=0.87, P=0.0009 ;$ Fig. 3 ). No amplification was observed in the noninoculated or nontarget species controls.

Assay sensitivity and limit of detection. Amplification of the target region of $16 \mathrm{D} 10$ through conventional PCR occurred in three of five samples inoculated with one nematode, all of the samples inoculated with five nematodes, four of the five samples inoculated with 10 nematodes, and four of the five samples inoculated with 20 nematodes per $0.5 \mathrm{~g}$ of soil. No amplification was observed in the noninoculated control.

Standard curves were generated from serial dilutions of DNA isolated from pure cultures of 1,000 M. hapla $\mathrm{J} 2$ and soil inoculated with $1,000 \mathrm{M}$. hapla $\mathrm{J} 2$, each representing a range of DNA concentrations from $\sim 790$ to $0.079 \mathrm{pg} / \mu \mathrm{l}$. The curve derived from assays of pure culture DNA extracts was described by $y=-3.065 x+22.738\left(R^{2}=\right.$ $0.99 ; P<0.001)$. The curve derived from assays of soil DNA extractions was described by $y=-3.656 x+28.596\left(R^{2}=0.68 ; P=0.05\right)$. Student's $t$ test analysis between mean Cq values resulted in a significant difference between soil and pure culture extracts at all dilutions except for the least dilute (1:1) level (Table 2), indicating that

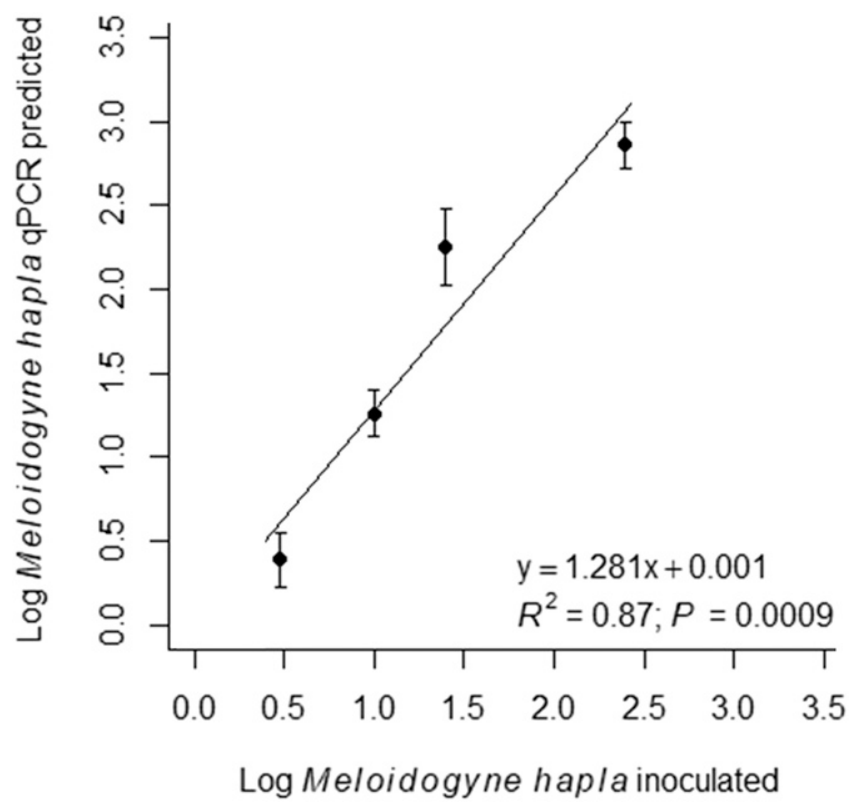

Fig. 3. The population standard curve based on the Mha17f/Mha17r primers targeting the $16 D 10$ effector gene was tested by inoculation of Meloidogyne hapla second-stage juveniles $(3,10,25$, and 250$)$ per $0.5 \mathrm{~g}$ of soil and calculation of predicted population density from resultant quantification cycle values. $\mathrm{qPCR}=$ quantitative PCR.

Table 2. The effect of soil inhibitors on the quantitative PCR assay for the detection of Meloidogyne hapla using the Mha17f/Mha17r primers targeting the $16 D 10$ effector gene was assessed ${ }^{\mathrm{a}}$

\begin{tabular}{lccl}
\hline Dilution & Cq soil $^{\mathbf{b}}$ & Cq pure culture $^{\mathbf{c}}$ & \multicolumn{1}{c}{$\boldsymbol{t}^{(\boldsymbol{P} \text { value })^{\mathbf{d}}}$} \\
\hline $1: 1$ & 30.93 & 22.74 & $3.44(0.17 ; \mathrm{ns})$ \\
$1: 10$ & 31.16 & 25.59 & $5.40(0.002)$ \\
$1: 100$ & 35.06 & 28.99 & $4.13(0.02)$ \\
$1: 1,000$ & 35.20 & 31.28 & $3.25(0.04)$ \\
$1: 10,000$ & 47.19 & 35.48 & $8.43(0.04)$ \\
\hline
\end{tabular}

${ }^{\text {a }}$ DNA was isolated from $M$. hapla second-stage juveniles (J2) in pure culture and from M. hapla J2 inoculated to soil. Serial dilutions were made from isolation products from approximately 790 to $0.079 \mathrm{pg} / \mu 1$ of $M$. hapla DNA.

${ }^{b}$ Mean quantification cycle $(\mathrm{Cq})$ value for dilutions from soil isolations.

${ }^{\mathrm{c}}$ Mean $\mathrm{Cq}$ values for dilutions from pure culture isolations.

${ }^{\mathrm{d}}$ Student's $t$ value. ns $=$ not significant. 
amplification inhibitors were present in a greater concentration within soil extracts, leading to higher $\mathrm{Cq}$ values.

Assessment of field samples. Nematode population density determined by manual counting and qPCR displayed a significant positive relationship $\left(R^{2}=0.41 ; P<0.001\right)$ and was described by the equation $\mathrm{y}=0.64 x-1.06$ (Fig. 4 ).

\section{Discussion}

qPCR remains an important tool in plant pathology research and diagnostics, circumventing potential problems related to accurate identification and quantification of plant-parasitic nematode populations. Yet the selection of a target region for a qPCR assay should be guided by the goals and objectives of the application, such as specific management questions or broader taxonomic studies (Ahmed et al. 2016; BraunKiewnick and Kiewnick 2018). Here, an accurate and reliable SYBR Green I qPCR based on the $16 D 10$ effector gene was developed for the detection and quantification of M. hapla from soil. The $16 D 10$ gene has been reported as unique to Meloidogyne spp. but with up to $30 \%$ sequence dissimilarity between orthologs in some species (Dinh et al. 2015). Sufficient polymorphism was observed between published sequences of the economically important species $M$. hapla, $M$. javanica, M. arenaria, and M. incognita to allow for the development of qPCR primers for detection of $M$. hapla. Testing with end-point PCR and qPCR confirmed the primers were highly species specific, exhibiting no crossreactivity with the other Meloidogyne spp. or plant-parasitic nematodes tested. The primers also amplified $M$. hapla isolates from diverse geographies, indicating that the assay has potential for use in diagnostics across broad regions. This degree of specificity is an improvement over ITS-based assays in which cross-reactivity of the primers with nontarget species was noted (e.g., Sapkota et al. 2016) and was of similar sensitivity to the ITS-based assay used by Hay et al. (2016). Indeed, similar improvements were observed by $\mathrm{Yu}$ et al. (2011) in a qPCR assay using the chorismate mutase effector gene for detection of selected Globodera species. However, in sensitivity experiments using conventional PCR, only four of five samples of those inoculated with either 10 or 20 $M$. hapla $\mathrm{J} 2$ nematodes produced visible product bands on an electrophoresis gel. This was likely attributable to potential inhibition of the sample rather than lack of sensitivity of the primers. Although this study provides additional support for the hypothesis that effector genes within plant-parasitic nematodes may be utilized as highly specific targets for detection and quantification, perspective should be retained; the $16 \mathrm{D} 10$ gene is still a relatively new area of effector research, with few published sequences available. A more comprehensive phylogenetic analysis of the 16010 gene among additional Meloidogyne species and regional isolates of $M$. hapla is ultimately needed to understand potential intraspecific gene variation within $16 D 10$ and to support a highly robust diagnostic test.

Huang et al. (2006a) predicted a gene copy number of $16 \mathrm{D} 10$ of three to four in Meloidogyne spp., based on DNA hybridization studies. The lower copy number of $16 D 10$ compared with the ITS region may account for the generally higher $\mathrm{Cq}$ values observed in this study compared with similar qPCR assays based on the Meloidogyne spp. ITS rDNA region, which is present in multiple copies (Blok 2005; Skantar and Carta 2005). A high degree of variability was observed between some replicates in the current study. The presence of $16 D 10$ at low copy number may preclude stochastic partitioning of template molecules into the reaction wells, resulting in greater variability, particularly for samples with a low nematode population density.

The effect of soil on reaction efficiency was evaluated and compared with manual extraction and morphology-based identification and quantification of M. hapla. The assay was highly sensitive and was able to detect one M. hapla $\mathrm{J} 2$ in $0.5 \mathrm{~g}$ of soil as determined through end-point PCR, with a sensitivity of approximately $0.079 \mathrm{pg} / \mu \mathrm{l}$. This sensitivity is comparable to ITSbased qPCR assays. For example, Sapkota et al. (2016) reported a lower limit of detection of $0.5 \mathrm{pg}$ for detection of $M$. hapla. The sensitivity of the qPCR developed here can support the economic threshold range of many susceptible crops, including carrot and lettuce, which have estimated action thresholds $<10 \mathrm{eggs} / \mathrm{cm}^{3}$
(Gugino et al. 2006; Viaene and Abawi 1996). However, the variation in samples containing one $M$. hapla $\mathrm{J} 2$ per $0.5 \mathrm{~g}$ of soil was high, indicating that several replicates are required to ensure accurate estimates. Using end-point PCR, the Mha17 primers exhibited a consistent lower limit of detection of five nematodes in $0.5 \mathrm{~g}$ of soil. Although the qPCR method described here was developed using $\mathrm{J} 2$ stage nematodes, many economic threshold values for populations of plant-parasitic nematodes are reported as eggs per volume of soil. Yan et al. (2013) found no significant difference in the $\mathrm{Cq}$ values produced from different life stages of the lesion nematode $P$. neglectus, suggesting that given a suitable DNA isolation method, different life stages may be quantified accurately. Yet this remains to be confirmed within Meloidogyne spp.

In this study, the $\mathrm{Cq}$ values from reactions using DNA isolated from pure culture were up to 11.7 cycles earlier than those using DNA isolated from soil using a commercial DNA extraction kit, suggesting that amplification inhibitors remain after soil DNA extraction. Furthermore, the amplification efficiency for samples isolated from soil was $118.3 \%$, above the expected $100 \%$. This increase in amplification efficiency is thought to be attributable to the action of polymerase inhibitors (Svec et al. 2015), indicating a reduction in the ability of the DNA extraction method to sufficiently remove contaminants. Soil type may also influence extraction efficiency, as it is observed that soils with high humic acid content (such as those with high clay content) are more difficult to separate contaminants (e.g., Miller et al. 1999; Zhou et al. 1996). Delayed amplification reflected by higher Cq values and variability using DNA extracts from soil also has the potential to be improved by more efficient soil DNA extraction and purification protocols, such as the addition of polyvinylpolypyrrolidone to the extraction buffer (Steffan et al. 1988; Zhou et al. 1996). It is therefore recommended that when deriving estimates of $M$. hapla population densities from soil DNA extracts using the method described here, one should account for this higher degree of variability and suboptimal amplification efficiency by including additional soil biological replicates and qPCR technical replicates within the assay. Within this, determining the optimal sampling density within an agricultural field for estimation of $M$. hapla population densities using this qPCR assay while maintaining cost-effectiveness is a logical next step.

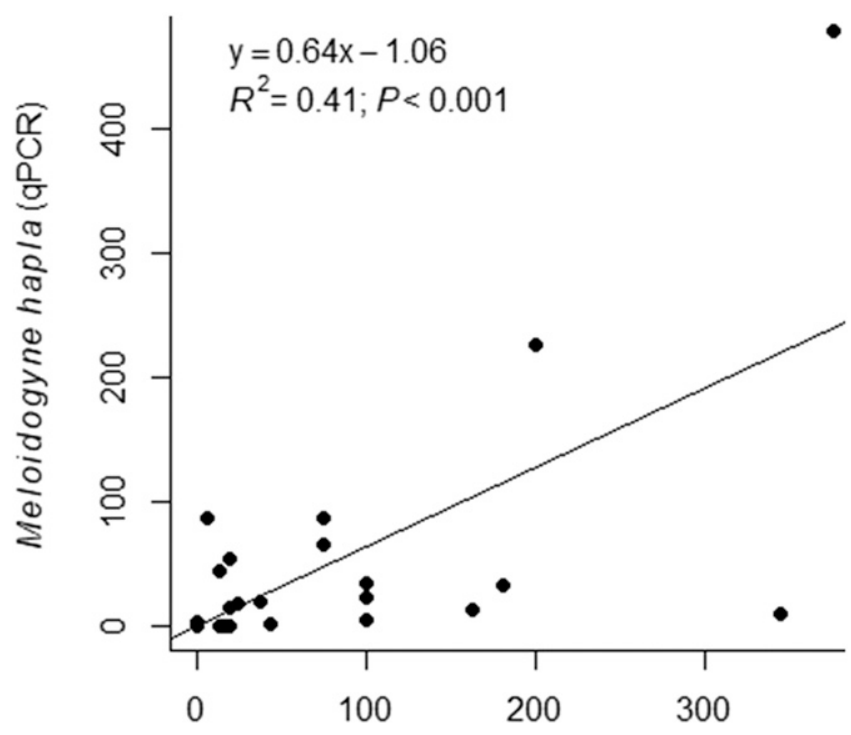

Meloidogyne hapla (manual counting)

Fig. 4. Relationship between Meloidogyne hapla population density estimates derived from morphology-based identification and from the quantitative PCR (qPCR) to evaluate the utility of the Mha17f/Mha17r primers for detection of $M$. hapla from potato fields in New York. 
A significant relationship was observed between M. hapla population estimates obtained by manual counting and qPCR, yet the sum of squares value was less $<1$, indicating deviation about the regression line. Indeed, some locations having high nematode counts in the manual extraction did not have corresponding high estimates within the qPCR assay. This variation may have resulted from inefficiencies and inconsistencies inherent to manual nematode extraction methods and potential nematode misidentification (Hay et al. 2016; Yan et al. 2012). The potential for error is also introduced into estimated values as a result of the logtransformation of populations (Toyota et al. 2008). The qPCR may therefore be more reliable for quantifying fold changes in nematode population densities, but smaller changes may be inherently less accurate.

The qPCR for detecting and quantifying $M$. hapla presented here provides an alternative for the need for lengthy manual extractions and error-prone morphology-based identification and is a resource for the continued monitoring of this species in many economically important agricultural crops. The use of effector genes as targets for qPCR provides species-specific quantification and advances nematode detection technologies by expanding the range of novel qPCR target regions.

\section{Acknowledgments}

We thank Andrea Skantar (U.S. Department of Agriculture Agricultural Research Service [USDA ARS], Beltsville, MD), Lance Cadle-Davidson (USDA ARS, Geneva, NY), Eric Davis (North Carolina State University, Raleigh, NC), and Nigel Perry (South Australian Research and Development Institute-Plant \& Soil Health, Adelaide, SA, Australia) for generously supplying nematode species for specificity and sensitivity testing; Carol Bowden, Elizabeth Burbine, and Sean Murphy for excellent technical assistance; and Noel Knight for constructive discussion.

\section{Literature Cited}

Adam, M. A. M., Phillips, M. S., and Blok, V. C. 2007. Molecular diagnostic key for identification of single juveniles of seven common and economically important species of root-knot nematode (Meloidogyne spp.). Plant Pathol. 56:190-197.

Agudelo, P., Lewis, S. A., and Fortnum, B. A. 2011. Validation of a real-time polymerase chain reaction assay for the identification of Meloidogyne arenaria. Plant Dis. 95:835-838.

Ahmed, M., Sapp, M., Prior, T., Karssen, G., and Back, M. A. 2016. Technological advancements and their importance for nematode identification. Soil (Gottingen) $2: 257-270$.

Anthoine, G., and Mugniéry, D. 2005. Variability of the ITS rDNA and identification of Nacobbus aberrans (Thorne, 1935) Thorne \& Allen, 1944 (Nematoda: Pratylenchidae) by rDNA amplification. Nematol. 7: 503-516.

Baidoo, R., Yan, G., Nagachandrabose, S., and Skantar, A. M. 2017. Developing a real-time PCR assay for direct identification and quantification of Pratylenchus penetrans in soil. Plant Dis. 101:1432-1441.

Bakhetia, M., Urwin, P. E., and Atkinson, H. J. 2007. qPCR analysis and RNAi define pharyngeal gland cell-expressed genes of Heterodera glycines required for initial interactions with the host. Mol. Plant-Microb. Interact. 20:306-312

Barker, K. R., and Olthof, T. H. 1976. Relationships between nematode population densities and crop responses. Annu. Rev. Phytopathol. 14:327-353.

Barker, K. R., Shoemaker, P. B., and Nelson, L. A. 1976. Relationships of initial population densities of Meloidogyne incognita and $M$. hapla to yield of tomato. J. Nematol. 8:232-239.

Berry, S. D., Fargette, M., Spaull, V. W., Morand, S., and Cadet, P. 2008. Detection and quantification of root-knot nematode (Meloidogyne javanica), lesion nematode (Pratylenchus zeae) and dagger nematode (Xiphinema elongatum) parasites of sugarcane using real-time PCR. Mol. Cell. Probes 22: 168-176.

Blok, V. C. 2005. Achievements in and future prospects for molecular diagnostics of plant-parasitic nematodes. Can. J. Plant Pathol. 27:176-185.

Braun-Kiewnick, A., and Kiewnick, S. 2018. Real-time PCR, a great tool for fast identification, sensitive detection and quantification of important plant-parasitic nematodes. Eur. J. Plant Pathol. 152:271-283.

Braun-Kiewnick, A., Viaene, N., Folcher, L., Ollivier, F., Anthoine, G., Niere, B., Sapp, M., van de Vossenberg, B., Toktay, H., and Kiewnick, S. 2016. Assessment of a new qPCR tool for the detection and identification of the root-knot nematode Meloidogyne enterolobii by an international test performance study. Eur. J. Plant Pathol. 144:97-108.

Curran, J., McClure, M. A., and Webster, J. M. 1986. Genotypic differentiation of Meloidogyne populations by detection of restriction fragment length difference in total DNA. J. Nematol. 18:83-86.
Dinh, P. T., Zhang, L., Mojtahedi, H., Brown, C. R., and Elling, A. A. 2015. Broad Meloidogyne resistance in potato based on RNA interference of effector gene 16D10. J. Nematol. 47:71-78.

Dong, K., Dean, R. A., Fortnum, B. A., and Lewis, S. A. 2001. Development of PCR primers to identify species of root-knot nematodes: Meloidogyne arenaria, M. hapla, M. incognita and M. javanica. Nematropica 31:271-280.

Duncan, L. W., and Phillips, M. S. 2009. Sampling root-knot nematodes. Pages 275-300 in: Root-Knot Nematodes. R. N. Perry, M. Moens, and J. L. Starr, eds. CAB International, Wallingford, UK.

Gao, B., Allen, R., Davis, E. L., Baum, T. J., and Hussey, R. S. 2004 Developmental expression and biochemical properties of a b-1,4endoglucanase family in the soybean cyst nematode, Heterodera glycines. Mol. Plant Pathol. 5:93-104.

García, L. E., and Sánchez-Puerta, M. V. 2012. Characterization of a root-knot nematode population of Meloidogyne arenaria from Tupungato (Mendoza, Argentina). J. Nematol. 44:291-301.

Gorny, A. M., Hay, F. S., Wang, X., and Pethybridge, S. J. 2018. Isolation of nematode DNA from $100 \mathrm{~g}$ of soil using $\mathrm{Fe}_{3} \mathrm{O}_{4}$ super paramagnetic nanoparticles. Nematology 20:271-283.

Goto, K., Sato, E., Gang, L. F., Toyota, K., and Sugito, T. 2010. Comparison of calibration curves prepared by soil compaction and ball milling methods for direct quantification of the potato cyst nematode Globodera rostochiensis in soil. Nematol. Res. 40:41-45.

Griffin, G. D., and Elgin, J. H., Jr. 1977. Penetration and development of Meloidogyne hapla in resistant and susceptible alfalfa under differing temperatures. J. Nematol. 9:51-56

Gugino, B. K., Abawi, G. S., and Ludwig, J. W. 2006. Damage and management of Meloidogyne hapla using oxamyl on carrot in New York. J. Nematol. 38: 483-490.

Haegeman, A., Mantelin, S., Jones, J. T., and Gheysen, G. 2012. Functional roles of effectors of plant-parasitic nematodes. Gene 492:19-31.

Hafez, S. L., Al-Rehiayani, S., Thornton, M., and Sundararaj, P. 1999 Differentiation of two geographically isolated populations of Pratylenchus neglectus based on their parasitism of potato and interaction with Verticillium dahliae. Nematropica 29:25-36.

Handoo, Z. A., Skantar, A. M., Carta, L. K., and Schmitt, D. P. 2005 Morphology and molecular evaluation of a Meloidogyne hapla population damaging coffee (Coffea arabica) in Maui, Hawaii. J. Nematol. 37:136-145.

Hay, F. S., Herdina, Ophel-Keller, K., Hartley, D. M., and Pethybridge, S.J. 2016. Prediction of potato tuber damage by root-knot nematodes using quantitative DNA assay of soil. Plant Dis. 100:592-600.

Holterman, M. H. M., Oggenfuss, M., Frey, J. E., and Kiewnick, S. 2012 Evaluation of high-resolution melting curve analysis as a new tool for rootknot nematode diagnostics: high-resolution melting curve analysis. J. Phytopathol. 160:59-66.

Huang, D., and Yan, G. 2017. Specific detection of the root-lesion nematode Pratylenchus scribneri using conventional and real-time PCR. Plant Dis. 101: 359-365.

Huang, D., Yan, G., Gudmestad, N., and Skantar, A. 2017. Quantification of Paratrichodorus allius in DNA extracted from soil using TaqMan Probe and SYBR Green real-time PCR assays. Nematology 19:987-1001.

Huang, G., Allen, R., Davis, E. L., Baum, T. J., and Hussey, R. S. 2006a Engineering broad root-knot resistance in transgenic plants by RNA silencing of a conserved and essential root-knot nematode parasitism gene. Proc. Nat. Acad. Sci. 103:14302-14306.

Huang, G., Dong, R., Allen, R., Davis, E. L., Baum, T. J., and Hussey, R. S. 2006b. A root-knot nematode secretory peptide functions as a ligand for a plant transcription factor. Mol. Plant-Microb. Interact. 19:463-470.

Huang, W. K., Peng, D. L., Zhang, D. S., Jiang, H. Y., Ding, Z., Peng, H., and Long, H. B. 2010. Assessment of genetic variability in population of Ditylenchus destructor (Thorne 1945) (Tylenchida: Anguinidae) from China. Russ. J. Nematol. 18:19-30.

Hugall, A., Stanton, J., and Moritz, C. 1999. Reticulate evolution and the origins of ribosomal internal transcribed spacer diversity in apomictic Meloidogyne. Mol. Biol. Evol. 16:157-164.

Janssen, G. J. W., van Norel, A., Verkerk-Bakker, B., and Janssen, R. 1995 Resistance to Meloidogyne chitwoodi, M. fallax and M. hapla in wild tuberbearing Solanum spp. Euphytica 92:287-294

Jeszke, A., Dobosz, R., and Obrępalska-Stęplowska, A. 2015. A fast and sensitive method for the simultaneous identification of three important nematode species of the genus Ditylenchus. Pest Manag. Sci. 71:243-249.

Jones, J. T., Furlanetto, C., Bakker, E., Blok, V., Chen, Q., Phillips, M., and Prior, A. 2003. Characterization of a chorismate mutase from the potato cyst nematode Globodera pallida. Mol. Plant Pathol. 4:43-50.

Jones, J. T., Haegeman, A., Danchin, E. G. J., Gaur, H. S., Helder, J., Jones, M. G. K., Kikuchi, T., Manzanilla-López, R., Palomares-Rius, J. E., Wesemael, W. M. L., and Perry, R. N. 2013. Top 10 plant-parasitic nematodes in molecular plant pathology. Mol. Plant Pathol. 14:946-961.

Kearse, M., Moir, R., Wilson, A., Stones-Havas, S., Cheung, M., Sturrock, S., Buxton, S., Cooper, A., Markowitz, S., Duran, C., Thierer, T., Ashton, B., Meintjes, P., and Drummond, A. 2012. Geneious Basic: An integrated and extendable desktop software platform for the organization and analysis of sequence data. Bioinformatics 28:1647-1649. 
Kiewnick, S., Frey, J. E., and Braun-Kiewnick, A. 2015. Development and validation of LNA-based quantitative real-time PCR assays for detection and identification of the root-knot nematode Meloidogyne enterolobii in complex DNA backgrounds. Phytopathology 105:1245-1249.

Kiewnick, S., Holterman, M., van den Elsen, S., van Megen, H., Frey, J. E., and Helder, H. 2014. Comparison of two short DNA barcoding loci (COI and COII) and two longer ribosomal DNA genes (SSU \& LSU rRNA) for specimen identification among quarantine root-knot nematodes (Meloidogyne spp.) and their close relatives. Eur. J. Plant Pathol. 140:97-110.

Koressaar, T., and Remm, M. 2007. Enhancements and modifications of primer design program Primer3. Bioinformatics 23:1289-1291.

Lambert, K. N., Allen, K. D., and Sussex, I. M. 1999. Cloning and characterization of an esophageal-gland-specific chorismate mutase from the phytoparasitic nematode Meloidogyne javanica. Mol. Plant-Microb. Interact. 12:328-336.

Madani, M., Subbotin, S. A., Ward, L. J., Li, X., and De Boer, S. H. 2010. Molecular characterization of Canadian populations of potato cyst nematodes, Globodera rostochiensis and G. pallida using ribosomal nuclear RNA and cytochrome b genes. Can. J. Plant Pathol. 32:252-263.

Madden, L. V., Hughes, G., and van den Bosch, F. 2007. The Study of Plant Disease Epidemics. American Phytopathological Society APS Press, St. Paul, MN.

Melakeberhan, H., Mennan, S., Chen, S., Darby, B., and Dudek, T. 2007. Integrated approaches to understanding and managing Meloidogyne hapla populations' parasitic variability. Crop Prot. 26:894-902.

Miller, D. N., Bryant, J. E., Madsen, E. L., and Ghiorse, W. C. 1999. Evaluation and optimization of DNA extraction and purification procedures for soil and sediment samples. Appl. Environ. Microbiol. 65:4715-4724.

Min, Y. Y., Toyota, K., and Sato, E. 2012. A novel nematode diagnostic method using the direct quantification of major plant-parasitic nematodes in soil by realtime PCR. Nematology 14:265-276.

Mitchum, M. G., Hussey, R. S., Baum, T. J., Xiaohong, W., Elling, A. A., Wubben, M., and Davis, E. L. 2013. Nematode effector proteins: An emerging paradigm of parasitism. New Phytol. 199:879-894.

Mitkowski, N. A., and Abawi, G. S. 2003. Root-knot nematode. Plant Health Instructor. Online resource.

Mokrini, F., Waeyenberge, L., Viaene, N., Abbad Andaloussi, F., and Moens, M. 2013. Quantitative detection of the root-lesion nematode, Pratylenchus penetrans, using qPCR. Eur. J. Plant Pathol. 137:403-413.

Mokrini, F., Waeyenberge, L., Viaene, N., Andaloussi, F. A., and Moens, M. 2014. The $\beta$-1,4-endoglucanase gene is suitable for the molecular quantification of the root-lesion nematode, Pratylenchus thornei. J. Nematol. 16:789-796.

Niu, J., Guo, Q., Jian, H., Chen, C., Yang, D., Liu, Q., and Guo, Y. 2011. Rapid detection of Meloidogyne spp. by LAMP assay in soil and roots. Crop Prot. 30:1063-1069.

Olthof, T. H. A., and Potter, J. W. 1972. Relationship between population densities of Meloidogyne hapla and crop losses in summer-maturing vegetables in Ontario. Phytopathology 62:981-986.

Ophel-Keller, K., McKay, A., Hartley, D., Herdina, and Curran, J. 2008. Development of a routine DNA-based testing service for soilborne diseases in Australia. Austral. Plant Pathol. 37:243-253.

Peng, H., Long, H., Huang, W., Liu, J., Cui, J., Kong, L., Hu, X., Gu, J., and Peng, D. 2017. Rapid, simple and direct detection of Meloidogyne hapla from infected root galls using loop-mediated isothermal amplification combined with FTA technology. Sci. Rep. 7:44853.

Perry, R. N., Moens, M., and Starr, J. L. 2009. Meloidogyne species - a diverse group of novel and important plant parasites. Pages 1-17 in: Root-Knot Nematodes. R. N. Perry, M. Moens, and J. L. Starr, eds. CAB International, Wallingford, UK.

Petersen, D. J., Zijlstra, C., Wishart, J., Blok, V., and Vrain, T. C. 1997. Specific probes efficiently distinguish root-knot nematode species using signature sequences in the ribosomal intergenic spacer. Fundam. Appl. Nematol. 20:619-626.

Powers, T. O., Todd, T. C., Burnell, A. M., Murray, P. C. B., Fleming, C. C., Szalanski, A. L., Adams, B. A., and Harris, T. S. 1997. The rDNA internal transcribed spacer region as a taxonomic marker for nematodes. J. Nematol. 29:441-450.

Prospero, S., Polomski, J., and Rigling, D. 2015. Occurrence and ITS diversity of wood-associated Bursaphelenchus nematodes in Scots pine forests in Switzerland. Plant Pathol. 64:1190-1197.

R Core Team. 2017. R: A Language and Environment for Statistical Computing. R Foundation for Statistical Computing, Vienna, Austria. https://www.R-project.org

Randig, O., Leroy, F., Bongiovanni, M., and Castagnone-Sereno, P. 2001. RAPD characterization of single females of the root-knot nematodes, Meloidogyne spp. Eur. J. Plant Pathol. 107:639-643.

Rehman, S., Gupta, V. K., and Goyal, A. K. 2016. Identification and functional analysis of secreted effectors from phytoparasitic nematodes. BMC Microbiol. 16:48.

Rich, J. R., Brito, J. A., Kaur, R., and Ferrell, J. A. 2008. Weed species as hosts of Meloidogyne: A review. Nematropica 39:157-185.

Roberts, P. A. 1992. Current status of the availability, development, and use of host plant resistance to nematodes. J. Nematol. 24:213-227.

Rybarczyk-Mydłowska, K., Mooyman, P., van Megan, H., van den Elsen, S., Vervoort, M., Veenhuizen, P., van Doom, J., Dees, R., Karssen, G., Bakker, J., and Helder, H. 2012. Small subunit ribosomal DNA-based phylogenetic analysis or foliar nematodes (Aphelenchoides spp.) and their quantitative detection in complex DNA backgrounds. Phytopathol. 102:1153-1160.
Sapkota, R., Skantar, A. M., and Nicolaisen, M. 2016. A TaqMan real-time PCR assay for detection of Meloidogyne hapla in root galls and in soil. Nematology 18:147-154.

Sawada, E., Mizuguchi, S., Sato, E., Min, Y.Y., Goto, K., Abe, N., Toyota, K., and Nakano, A. 2011. Development of a direct quantitative detection method for Meloidogyne incognita in sandy soils and its application to sweet potato cultivated fields in Tokushima prefecture, Japan. Nematology 13:95-102.

Seinhorst, J. W. 1965. The relation between nematode density and damage to plants. Nematologica 11:137-154.

Skantar, A. M., and Carta, L. K. 2005. Multiple displacement amplification (MDA) of total genomic DNA from Meloidogyne spp. and comparison to crude DNA extracts in PCR of ITS1, 28S D2-D3 rDNA and Hsp90. Nematol. 7:285-293.

Smant, G., and Jones, J. 2011. Suppression of Plant Defenses by Nematodes. Springer, Dordrecht, The Netherlands.

Steffan, R. J., Goksoyr, J., Bej, A. K., and Atlas, R. M. 1988. Recovery of DNA from soils and sediments. Appl. Environ. Microbiol. 54:2908-2915.

Svec, D., Tichopad, A., Novosadova, V., Pfaffl, M. W., and Kubista, M. 2015. How good is a PCR efficiency estimate: Recommendations for precise and robust qPCR efficiency assessments. Biomol Detect. Quantif. 3:9-16.

Toumi, F., Waeyenberge, L., Viaene, N., Dababat, A. A., Nicol, J. M., Ogbonnaya, F. C., and Moens, M. 2015. Development of qPCR assays for quantitative detection of Heterodera avenae and H. latipons. Eur. J. Plant Pathol. 143:305-316.

Toyota, K., Shirakashi, T., Sato, E., Wada, S., and Min, Y. Y. 2008. Development of a real-time PCR method for the potato-cyst nematode Globodera rostochiensis and the root-knot nematode Meloidogyne incognita. Soil Sci. Plant Nutn. 54:72-76.

Untergasser, A., Cutcutache, I., Koressaar, T., Ye, J., Faircloth, B. C., Remm, M., and Rozen, S. G. 2012. Primer3 - new capabilities and interfaces. Nucleic Acids Res. 40:e115.

van der Beek, J. G., Poleij, L. M., Zijlstra, C., Janssen, R., and Janssen, G. J. W. 1998. Variation in virulence within Meloidogyne chitwoodi, M. fallax, and M. hapla on Solanum spp. Phytopathology 88:658-665.

Vanholme, B., Van Thuyne, W., Vanhouteghem, K., De Meutter, J., Cannoot, B., and Gheysen, G. 2007. Molecular characterization and functional importance of pectate lyase secreted by the cyst nematode Heterodera schachtii. Mol. Plant Pathol. 8:267-278.

Viaene, N. M., and Abawi, G. S. 1996. Damage threshold of Meloidogyne hapla to lettuce in organic soil. J. Nematol. 28:537-545.

Vrain, T. C. 1982. Relationship between Meloidogyne hapla density and damage to carrots in organic soils. J. Nematol. 14:50-57.

Walker, G. E. 1997. Effects of Meloidogyne spp. and Rhizoctonia solani on the growth of grapevine rootings. J. Nematol. 29:190-198.

Wheeler, T. A., Madden, L. V., Riedel, R. M., and Rowe, R. C. 1994. Distribution and yield-loss relations of Verticillium dahliae, Pratylenchus penetrans, $P$. crenatus, and Meloidogyne hapla in commercial potato fields. Phytopathology 84:843-852.

Whitehead, A. G., and Hemming, J. R. 1965. A comparison of some quantitative methods of extracting small vermiform nematodes from soil. Ann. Appl. Biol. 55:25-38

Wishart, J., Phillips, M. S., and Blok, V. C. 2002. Ribosomal intergenic spacer: A polymerase chain reaction diagnostic for Meloidogyne chitwoodi, M. fallax, and M. hapla. Phytopathology 92:884-892.

Yan, G., Smiley, R. W., and Okubara, P. A. 2010. Identification and quantification of Pratylenchus neglectus and P. thornei from soils in the Pacific Northwest using real-time polymerase chain reaction. J. Nematol. 42:277-278.

Yan, G., Smiley, R. W., and Okubara, P. A. 2012. Detection and quantification of Pratylenchus thornei in DNA extracted from soil using real-time PCR Phytopathology 102:14-22.

Yan, G., Smiley, R. W., Okubara, P. A., Skantar, A., Easley, S. A., Sheedy, J. G., and Thompson, A. L. 2008. Detection and discrimination of Pratylenchus neglectus and P. thornei in DNA extracts from soil. Plant Dis. 92:1480-1487.

Yan, G., Smiley, R. W., Okubara, P. A., Skantar, A. M., and Reardon, C. L. 2013. Developing a real-time PCR assay for detection and quantification of Pratylenchus neglectus in soil. Plant Dis. 97:757-764.

Yu, H., Chronis, D., Lu, S., and Wang, X. 2011. Chorismate mutase: An alternatively spliced parasitism gene and a diagnostic marker for three important Globodera nematode species. Eur. J. Plant Pathol. 129:89-102.

Zhou, J., Burns, M. A., and Tiedje, J. M. 1996. DNA recovery from soils of diverse composition. Appl. Environ. Microbiol. 62:316-322.

Zijlstra, C. 1997. A fast PCR assay to identify Meloidogyne hapla, M. chitwoodi, and $M$. fallax, and to sensitively differentiate them from each other and from M. incognita in mixtures. Fundam. Appl. Nematol. 20:505-511.

Zijlstra, C. 2000. Identification of Meloidogyne chitwoodi, M. fallax, and M. hapla based on SCAR-PCR: A powerful way of enabling reliable identification of populations or individuals that share common traits. Eur. J. Plant Pathol. 106: 283-290.

Zijlstra, C., Lever, A. E. M., Uenk, B. J., and Van Silfhout, C. H. 1995. Differences between ITS regions of isolates of root-knot nematodes Meloidogyne hapla and M. chitwoodi. Phytopathology 85:1231-1237.

Zijlstra, C., and Van Hoof, R. A. 2006. A multiplex real-time polymerase chain reaction (TaqMan) assay for the simultaneous detection of Meloidogyne chitwoodi and M. fallax. Phytopathology 96:1255-1262. 